\title{
Comparative Study of Branding in Iranian Public Hospitals and Some other Public Hospitals in Selected Countries
}

\author{
Elham Afzal ${ }^{1}$, Mohammad Hossein Modarresi², \\ Mohammad Reza Maleki ${ }^{3}$ and Amir Ashkan Nasiripour ${ }^{4}$ \\ ${ }^{1}$ Department of Health Care Administration, College of Medical Sciences, \\ Science and Research Branch, Islamic Azad University, Tehran, Iran. \\ ${ }^{2}$ Department of Biology, Science and Research Branch, Islamic Azad University, Tehran, Iran. \\ ${ }^{3}$ School of Management and Medical Information Services, \\ Iran University of Medical Sciences, Tehran, Iran. \\ ${ }^{4}$ Department of Health Care Administration, College of Medical Sciences, \\ Science and Research Branch, Islamic Azad University, Tehran, Iran. \\ http://dx.doi.org/10.13005/bbra/2036
}

(Received: 04 February 2016; accepted: 11 March 2016)

\begin{abstract}
Applying branding models by health sectors of other countries, leads to delivering quality products and services tailored to customer needs. The objective was a comparative study of branding in Iranian public hospitals and some other public hospitals in selected countries. In this descriptive-comparative study, hospitals that have implemented successful branding were selected from Britain, Canada, Australia, New Zealand, China, Ireland, South Korea and South Africa. A similar public hospital in Iran was also entered in this study. To collect data of hospitals under study, papers, and dissertations of electronic databases i.e. NHS, WHO and reports of selected hospitals were utilized. Collected data were summarized and classified based on the variables of the study and compared and analyzed in comparative tables. Each of the hospitals under study has taken some measures such as organization's competitive position, branding strategies, established brand and relationship with customers and has utilized the results to attract more patients and reduce the health expenditures; While Iran has limited experience in using this model in public hospitals. With regard to actions taken in selected hospitals to extend the branding, using their experiences in Iran, drafting, and adoption of policies and guidelines in this regard due to Iran's local conditions are highly recommended.
\end{abstract}

Keywords: Hospital Brand, Branding, Public Hospitals

In today's competitive world all organizations such as health care organizations are paying greater attention to providing products and services with unique quality and in compliance with customers' needs. In fact, in order to survive, organizations must inevitably adapt themselves with global situations and market utility ${ }^{1}$.

Growing health care expenses, less control over selection, lower service quality and

\footnotetext{
* To whom all correspondence should be addressed.
}

patient satisfaction and big changes in health culture and healthcare system are among the challenges hospitals face in Iran. Therefore, it is necessary for them to revise the ways services are provided and modify their business structure in order to adapt with changes. To achieve long term success it is definitely essential to recognize present situation and unique stable condition of hospitals. More than anything, creating and transferring positive changes, having stable emotional relationships with patients and their families is important. Meanwhile, these challenges are suitable opportunities for hospitals to create a powerful 
brand for themselves and attract more customers ${ }^{2}$.

Most of the non trading organizations and centers like hospitals and health care centers are not positive about marketing and branding and some even say it's opposed to professional ethics. This is rooted in lack of knowledge about marketing concepts and branding. Hospitals and other health care centers are strongly in need of an effective marketing plan. In contrary, they just analyze target market in final stages of services production. In other words, marketing and brand improvement is not merely advertisement but is meeting customer needs and requirements in an organized way ${ }^{3}$.

Brand bridges the gap between organization output and fame and customers needs and investors hopes ${ }^{4}$. Powerful brands help organizations to have independent valuable identity in related market and to be less vulnerable tocompetitive activities, earn more profit and have more chance of improving their brand ${ }^{5}$. A powerful brand is a way for reducing customer challenges in choosing service provider ${ }^{6}$.

Successful hospital brands increases confidence in intangible services and customers can clearly imagine and recognize their services. Also a high level of special brand value increases the level of customer satisfaction, repeated visits and level of loyalty ${ }^{7}$.

In recent years distinguishing service philosophy in health care services is rapidly turning into the last wave of change. In this regard, service systems like hospitals especially private hospitals around the world; have taken effective steps in implementing this kind of thinking. The goal of using and implementing this philosophy is patient attraction, satisfaction and confidence. In Iran public hospitals pay less attention to branding.

Recognizing successful experiences of public hospital around the world can open the door to laying the ground for branding in public hospitals. Thus the present study aims at conducting an adaptive study of branding variables in public hospitals in selective countries.

\section{Research Method}

This study is a practical research which is conducted in adaptive-descriptive way. Data was gathered through library research about how hospital branding has been done in different public hospitals around the world. Therefore, the study population includes public hospitals which have been branding. Researchers picked 8 public hospitals from 8 countries using experts and specialists advice. The hospitals include: York hospital from London, Alberta children's hospital from Canada, Fiona Stanley Hospital from Australia, Middlemore Hospital fromN, Xuzhou Central Hospital from China, Cork University Hospital from Ireland, Seoul National University Hospital from South Korea, Chris Hani Baragwanath Hospital from South Africa. Then effective factors on branding their hospitals were compared with each other and similar case of ShahidHashemiNezhad hospital in Tehran.

Data was gathered by searching key words in electronic databases for article and thesis, NHS and WHO websites and reports from selective countries in the field of hospital branding. Data related to Iranian hospital ShahidHashemiNezghadsubspecialty hospital in Tehran- was gathered through reviewing articles, books, reports, minutes of meetings and conference texts related to the hospital and also through talking to senior officials.

Data was summarized and categorized based on research variables and were compared and analyzed in adaptive tables. Research variables or in other words effective factors on public hospitals branding includes competitive positioning of the organization, branding strategies, brand positioning and customer relationship.

\section{Findings}

Subject public hospitalshave done branding and were successful in this field. According to the studies, mainly in these hospitals objective efforts have been done for improving strong points, outcomes and titles earned by hospital. For example York hospital in England introduced itself as the first rank for the highest reception rate in the region, the best service provider in the region and candidate of many prizes, and also focuses on having skilled doctors and qualified personnel. Another example is Alberta children's hospital in Canada. This hospital is a brand in city planning and a leading center for providing services in the geographic region ${ }^{8}$ this hospital publishes accurate financial audits and annual reports ${ }^{9}$. This hospital also has the highest rate of activity in emergency department in the region $^{10}$. Thus the above mentioned hospitals 
Table 1. Summary of adaptive research results of effective components on branding in selective hospitals

\begin{tabular}{|c|c|c|c|c|}
\hline 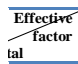 & Brand positioning & Competitive position of the brand & Branding strategy & $\begin{array}{l}\text { The relationship between brand and } \\
\text { market and customer }\end{array}$ \\
\hline $\begin{array}{l}\text { INational } \\
\text { iversity } \\
\text { spital - } \\
\text { thKorea }\end{array}$ & $\begin{array}{l}\text { - The first national hospital in South } \\
\text { Korea } \\
\text { - First ranking based on brand } \\
\text { power in health care during } 9 \\
\text { years. } \\
- \text { Agenda setting of acquired titles } \\
-\quad \text { Role of agenda setting in order to } \\
\text { train human resources. }\end{array}$ & 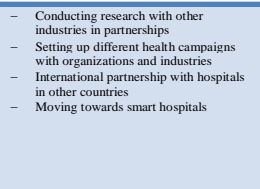 & $\begin{array}{l}\text { Running the hospital as a complex that } \\
\text { provides services } \\
\text { - Setting up and installation of quality } \\
\text { assurance program in hospitial departments } \\
\text { - Establishing clinical trial center in hospital } \\
\text { in order to develop research } \\
\text { - Attending in student exchange programs } \\
\text { internationally } \\
\text { - Designing a website for the hospital in } 15 \\
\text { different languages } \\
\text { - Joining the research supporter hospitals } \\
\text { group in South Korea }\end{array}$ & 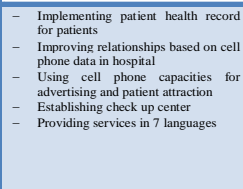 \\
\hline $\begin{array}{l}\text { Hospital- } \\
\text { ggland }\end{array}$ & $\begin{array}{l}- \text { Highest rank of patient admission } \\
\text { compared to other hospitals in the } \\
\text { region. } \\
\text { - The most important hospital } \\
\text { providing services in England } \\
- \text { Selective advertisement and } \\
\text { attending the final stages of } \\
\text { getting prizes among England } \\
\text { hospitals } \\
\text { - Introducing personnel, professors } \\
\text { and specialists }\end{array}$ & 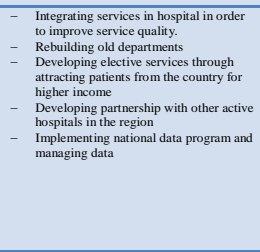 & $\begin{array}{l}\text { Paying attention to savings through internal } \\
\text { - hospital function } \\
\text { Installation of risk management and clinical } \\
\text { audit } \\
\text { - Partership with army in order to provide } \\
\text { services to military in the geographic } \\
\text { region } \\
\text { - Planning to preserve the existing patients } \\
\text { and three percent increase in the number of } \\
\text { admitted patients } \\
\text { New investments to equip new medical } \\
\text { Nequipments } \\
\text { - Developing dialysis plan according to the } \\
\text { regions demand } \\
\text { - Improving telemedicine program by the } \\
\text { hospital }\end{array}$ & $\begin{array}{l}\text { - Using health volunteers in order to } \\
\text { provide services especially among } \\
\text { patients supporter } \\
\text { - Having patient feedback policies } \\
\text { using telephone, lap top, tablet and so } \\
\text { forth data. } \\
\text { - Paying attention to the patient as the } \\
\text { - core of hospital function } \\
-\quad \text { vealuating patient satisfaction of } \\
\text { hospitalized patients, their families } \\
\text { and friends. }\end{array}$ \\
\hline $\begin{array}{l}\text { ris Hani } \\
\text { Igwanath } \\
\text { ital South } \\
\text { Ifrica }\end{array}$ & $\begin{array}{l}- \text { Introducing hospital as one of the } \\
\text { biggest hospitals in the world } \\
\text { based on the number of beds } \\
-\quad \text { Scientific partnership in the field } \\
\text { of mental health with other } \\
\text { organizations } \\
-\quad \text { Using advertisement capacity to } \\
\text { conduct hospital projects } \\
- \text { Placing the hospital in the list of } \\
\text { leading hospitals doing national } \\
\text { projects }\end{array}$ & 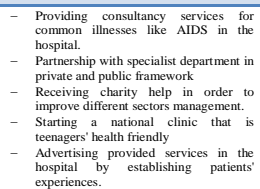 & 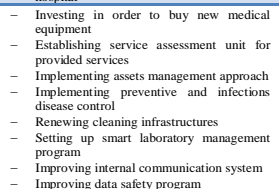 & $\begin{array}{ll}- & \text { Reducing mother infant deaths by } \\
\text { increasing ICU beds } \\
- & \text { Providing the highest quality services } \\
\text { to patients } \\
- & \text { Installing complaint management } \\
\text { system with regular evaluation } \\
- \\
- & \text { Proximity to public transportation } \\
- & \text { Setting up different general health } \\
\text { campaigns and increasing health } \\
\text { education in society } \\
- \text { Providing at home services to } \\
\text { patients }\end{array}$ \\
\hline $\begin{array}{l}\text { dlemore } \\
\text { jital New } \\
\text { ealand }\end{array}$ & $\begin{array}{l}- \text { Introducing hospital as an } \\
\text { executive hospital in the country } \\
\text { - Introducing the hospital as } \\
\text { narcotic free (patients, personnel } \\
\text { and environment) } \\
\text { - Having a leading role in treating } \\
\text { some common disease in the } \\
\text { region } \\
\text { - Agenda setting of getting different } \\
\text { acquired prizes }\end{array}$ & $\begin{array}{l}\text { - Developing a thome services } \\
\text { - } \\
\text { Investing in infrastructures and hospital } \\
\text { equipments } \\
\text { Special plan for health care for patients } \\
\text { - ast ste suggesested package } \\
\text { - Implementing service quality models } \\
\text { like clinical supremacy } \\
\text { - Providing developed diabetes services } \\
\text { according to region's demand }\end{array}$ & $\begin{array}{l}\text { - Implementing new health care model for } \\
\text { higher demanding groups in a geographic } \\
\text { region } \\
-\quad \text { stablish a weblog for executive team } \\
-\quad \text { Supporting personnel against violence } \\
-\quad \text { Providing consultancy services to } \\
\text { alcoholics according to regional demand } \\
\text { - Providing consultancy to alcohol users } \\
\text { according to regional lemand } \\
\text { - Doing basic key researches } \\
-\quad \text { Improving and developing educational } \\
\text { activities }\end{array}$ & $\begin{array}{l}\text { - Designing healthcare action } \\
\text { - processes for patients } \\
\text { - Settring up the first care unit for heart } \\
\text { attack patients in New Zealand } \\
- \text { Providing free transportation services } \\
- \text { Having a complaint assessment office } \\
- \text { Providing religious volunteer services } \\
- \text { Presence of the hospital in social } \\
\text { networks }\end{array}$ \\
\hline $\begin{array}{l}\text { University } \\
\text { tal Ireland }\end{array}$ & $\begin{array}{ll}\text { - } & \text { Introducing the hospital as the } \\
\text { biggest educational hospital in } \\
\text { IIreland } \\
-\quad \text { Locating in center of the city as a } \\
\text { strategic location } \\
- & \text { Introducing hospital as a narcotic } \\
\text { free hospitital } \\
- & \text { Among the leading hospitals of } \\
\text { continental plan for clinical audit } \\
\text { of deaths cases }\end{array}$ & 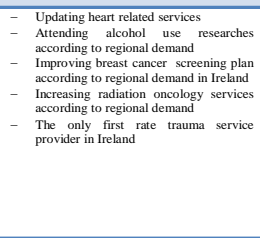 & $\begin{array}{l}\text { - Partnership with private sector in providing } \\
\text { services } \\
\text { - Providing services to patients with different } \\
\text { insurance programs } \\
\text { - Regular plan for improving service quality } \\
\text { through patient satisfaction evaluation } \\
\text { - Ttudies } \\
\text { She leading hospital in providing nursing } \\
\text { - education hon } \\
\text { Advanced plan for controlling infectious } \\
\text { disease as the first active hospital in this } \\
\text { field in Ireland } \\
-\quad \text { Setting up and developing national mother } \\
\text { infant health management } \\
\text { - Integrative medical and surgery plan }\end{array}$ & 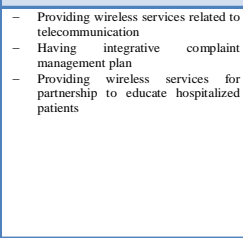 \\
\hline $\begin{array}{l}\text { uzhou } \\
\text { entral } \\
\text { sspital } \\
\text { zhina }\end{array}$ & $\begin{array}{l}\text { - Stating the glories and certificates } \\
\text { acquired by the hospitial } \\
\text { - Welcoming and inviting different } \\
\text { medias for sending reports from } \\
\text { hospitals } \\
\text { - Publishing most important events, } \\
\text { reporting hospital activities and } \\
\text { expenses data in hospital } \\
\text { magazine }\end{array}$ & $\begin{array}{l}\text { Try to be the role model hospital for } \\
\text { local and regional hospitals } \\
\text { - Leading in implementing submitted } \\
\text { plans by organizations and superior } \\
\text { organizations } \\
\text { - Introducing hospital as the leading } \\
\text { hospital in providing charity services } \\
\text { specially paying attention to WHO plans }\end{array}$ & $\begin{array}{l}\text { Providing services with } 3 \text { visits after } \\
\text { clearance for follow up } \\
-\quad \text { Providing extra services like transportation } \\
\text { to the hospital, daily care and so forth } \\
-\quad \text { Setting up non communicable disease } \\
\text { campaigns to tantract more patients } \\
\text { - Asking physicians to provide specific } \\
\text { consultancy services to active specialist } \\
\text { groups in villages trough educational plan } \\
\text { - Creating VIP departments for specific } \\
\text { patients like organizational managers and } \\
\text { famous people }\end{array}$ & 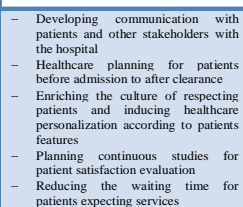 \\
\hline $\begin{array}{l}\text { lberta } \\
\text { ildren's } \\
\text { sspital } \\
\text { anada }\end{array}$ & $\begin{array}{l}\text { - Introducing the hospital as the } \\
\text { leading center of providing } \\
\text { services in the geographic region } \\
\text { - Introducing past, present and } \\
\text { future plans using the time capsule } \\
\text { idea } \\
\text { - Reporting and accurate financial } \\
\text { audit and publishing annual } \\
\text { reports }\end{array}$ & $\begin{array}{l}\text { - Partnership and developing volunteer } \\
\text { plans by the hospital } \\
\text { - Improving brain and nerve services for } \\
\text { children } \\
\text { S Setring up scientific conference } \\
- \text { Installation of advanced medical } \\
\text { equilment } \\
\text { - Welcoming innovative ideas and plans } \\
\text { through using suitable communication } \\
\text { ways }\end{array}$ & 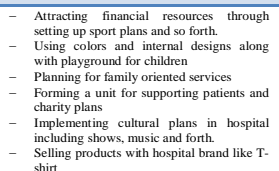 & $\begin{array}{l}\text { - Considering accommodation for } \\
\text { patientrelatives wireless internet, } \\
\text { - Providing } \\
\text { computer, video games and renting } \\
\text { lap top to patients } \\
\text { - Dedicating parking to patient families } \\
\text { - Preserving privacy and safety for } \\
\text { patients and families }\end{array}$ \\
\hline $\begin{array}{l}\text { iona } \\
\text { tanley } \\
\text { כspital } \\
\text { istralia }\end{array}$ & $\begin{array}{l}\text { - One of the biggest hospitals in the } \\
\text { geographic region in Australia } \\
\text { - Asset strategic managanent in the } \\
\text { - } \text { hospital } \\
\text { Providing third level services the } \\
\text { best way possible }\end{array}$ & 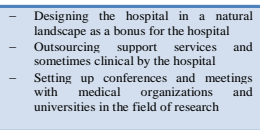 & $\begin{array}{ll}\text { - Designing hospital based on energy } \\
\text { efficiency standard as the } 4 \text { star hospital } \\
\text { - Practical synergy with private sector with } \\
\text { - proximity } \\
\text { - Forming service providing network with } \\
\text { other hospitals in the egeographic region } \\
\text { - Providing clinical support to other hospitals } \\
\text { and service providers }\end{array}$ & 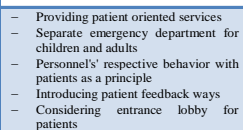 \\
\hline $\begin{array}{l}\text { dHashem } \\
\text { ezhad } \\
\text { sspital }\end{array}$ & $\begin{array}{l}\text { Stating glories and certificates of } \\
\text { the hospital } \\
\text { Considering slogan for } \\
\text { advertisement sognt } \\
\text { - Publishing articles and attending } \\
\text { different congresses in order to } \\
\text { improve scientific aspect of the } \\
\text { hospital } \\
- \text { Welcoming and inviting different } \\
\text { medias for introducing to hospital }\end{array}$ & 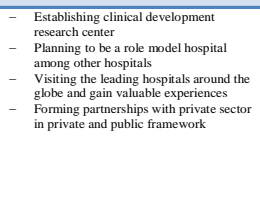 & $\begin{array}{l}\text { - Completing the providing services chain in } \\
\text { partrership with private sector } \\
\text { - Implementing specific plans to attract } \\
\text { human resources and preserving them } \\
-\quad \text { Taking part in sport and cultural programs } \\
\text { to introduce the hospital better } \\
-\quad \text { Using color and designs for different } \\
\text { departments } \\
-\quad \text { Creating specific departments for special } \\
\text { patients } \\
-\quad \text { Providing services after clearance in order } \\
\text { to develop follow up for patients }\end{array}$ & 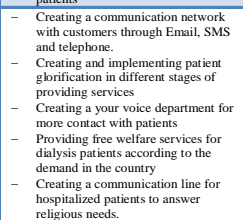 \\
\hline $\begin{array}{l}\text { JRajaeiCa } \\
\text { gy } \\
\text { al }\end{array}$ & $\begin{array}{l}\text { One of ten biggest cardiology } \\
\text { hospitals in the world } \\
\text { - Scientific hub of cardiovascular } \\
\text { d disease in the country } 10 \text { heart } \\
\text { - Doing more than } 10 \text { ing } \\
\text { implantation annually. } \\
\text { - Gaining certificates and high } \\
\text { rankings } \\
\text { - Providing specific services to } \\
\text { government officials }\end{array}$ & 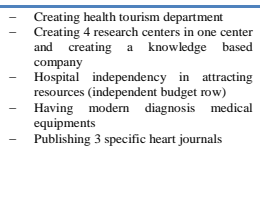 & $\begin{array}{l}\text { - Cooperating with Iran heart charity } \\
\text { foundation } \\
\text { - Setting up a genetic laboratory } \\
\text { - Supporting practical research } \\
\text { - Evaluating providing services and } \\
\text { continuously improve the quality of the } \\
\text { services } \\
\text { - Developing sub specialty services for } \\
\text { children according to the demand }\end{array}$ & $\begin{array}{l}- \text { Publishing magazine to inform } \\
\text { patients and provide them with more } \\
\text { information } \\
\text { - Forming a customer communication } \\
\text { unit } \\
\text { - Visual and audio eductiotions through } \\
\text { media of heart hub of Iran in hospital } \\
\text { site } \\
\text { - Psychology clinic for educating and } \\
\text { consulting patients before } \\
\text { hospitalization, also for educating } \\
\text { their supporter, hospitalized patients, } \\
\text { free visitors and personnel. }\end{array}$ \\
\hline
\end{tabular}


made a move for branding.

Regarding competitive positioningSeoul National University Hospital from South Korea did a series of actions including doing research with other industries, setting up different health campaigns with other organizations, international partnerships with hospitals around the globe, using modern equipments and moving towards being a smart hospital ${ }^{11-14}$. Chris Hani Baragwanath Hospital in South Africa developed AIDS treatment services regarding the need of the region ${ }^{15}$. The hospital cooperates with public sector in the form of public-private partnership ${ }^{16}$ and has used charity helps from other organizations for improving different sectors as a way of improving hospital services ${ }^{17}$. Baragwanath has also designed and implemented strategic plans ${ }^{18}$.

Each of the subject hospitals use a strategy for hospital branding like Cork University Hospital in Ireland. Cork University hospital implementsthese strategies: comprehensive medical and surgery evaluations ${ }^{19}$, providing services with different insurance schemes ${ }^{20}$, reducing risk plan ${ }^{21}$,and advanced infectious control plan as the first active hospital in this field in Ireland ${ }^{22}$. Xuzhou Central Hospital in China has also implemented similar strategies like: providing services with 3 visits policy after clearance in order to develop follow up activities among patients, providing extra services like transfer to hospital, daily care at home and so forth, preparing VIP for special patients like organization managers and famous people, physicians must necessarily provide specialized consultation to active specialized groups in villages through educational programs $^{23-24}$.

Preserving brand positioning among customers and in the market as the effective factor in hospital branding, relates to improving the relationship between brand and customers and market. This has been in focus in conducting research on subject hospitals. Among them Fiona Stanley Hospital in Australia provides patient oriented services ${ }^{25}$. In Fiona Stanleypatient feedback paths have been introduced and patient are more satisfied with unique services and environment of the hospital (this hospital is designed in nature ${ }^{26}$. In Middlemore Hospital in New Zealand some healthcare action processes have been designed ${ }^{27}$ and free transportation services are available for patients ${ }^{28}$.

Shahid Hashemi Nezhad public hospital as a brand hospital in the specific field of kidney and urinary tracts and ShahidrRajaei hospital in Tehran as the brand hospital in cardiovascular disease have conducted interventions for being distinguished or that is to say branding. For example, ShahidHashemiNezhad hospital has introduced gained glories and credits, attracted experienced personnel and famous physicians, officials have visited leading hospitals over the boarders, they have had successful experiences, the hospital has also completed the service providing chain with partnerships of private sector, and prepared a treatment program before admission which continous after the clearance and such acts. So the brand is more valid [29] [30] [31]. ShahidRajaei hospital in Tehran has been recognized as one of ten cardiology centers Inthe world and provides integrative services to patients, develops subspecialty servicesfor children, has created health tourism department and diplomat department for foreigner patients and government officials, doing more than 10 heart implant annually and sending physicians and personnel to national and international scientific events, having modern medical equipments and continuously improve brand services ${ }^{32-33}$.

Summary of subject hospital actions regarding subject variables are presented in table 1 (adaptive table of subject variables in selective hospitals).

\section{DISCUSSION}

Findings of the present research shows that the subject hospitals know the benefits of branding for attracting more patients and increasing credit and fame and consider planned actions for hospital branding. Therefore, they believe in brand positioning and try to increase their market share through brand image positioning. Subject hospitals lay the ground for customer confidence through introducing their skills, strong points and outcomes so that customers choose them relying on concrete measures. Helen et al., reached similar results and emphasized that "strong hospital brands severely increase the need for intangible products and it's more likely that customers buy their product, visit again or be loyal 
to them. Thus, recently hospital brand image has turned into an important factor for comparing hospitals by customers ${ }^{7}$.

Success of branding projects among public hospitals relies on competitive ability. Hospitals tendency towards offering distinguished quality and according to customers' needs helps them be superior and valuable among customers. This also increases personality and serf confidence $^{34}$. In subject hospitals in the present study competitive policies have been observed, which are a way of improving the level of performance and service acceptance ${ }^{35}$. Seoul National University also uses international partnership with other countries hospitals as a competitive policy because "change and adaption of services with new circumstances and needs is one of the reasons a brand lives a long life compared with competitors ${ }^{36}$.Yassin, Nour and Mohammad concluded that competitive activities leads the organization to more profit and chances for developing brand and this confirms the importance of competitive positioning of the brand ${ }^{5}$.

Brand strategy improves the organization brand with recognizing customer favorableness and unique identity for the services and products and this Way brings value for the customer and identity for the organization ${ }^{37}$.Nafisi (1388) stated that most of health care organizations have limited experiences in developed branding strategy. The reason is less knowledge regarding the brand and its role in general organizational strategy ${ }^{36}$. In subject hospitals branding strategies are used for developing services magnitude and improving quality and using innovation. According to Sorayaei and Mehraei, following correct branding strategies, leads to organization positioning in the market $^{38}$. Thus, subject hospitals tried to improve their brand using branding strategies.

Desired relationship of the organization with customer is a solution for long term customer satisfaction it even starts before direct contact with the customer and continues after the contact ${ }^{35}$. In subject hospitals the relationship of the brand with customers is made with electronic media networks and advertisement also having effective behavioral relationship and customer desired services. In their study Kim Kim and Kong suggested that customer relationship is one of the suitable ways for growth and improvement and increasing the value of the brand. To do so Service departments try to make a relationship with customers and make a positive image for them through the effects of services on customers' perception. Also for increasing loyalty to brand and brand value and in order to meet customers' needs in hospital service sector, relationship marketing activities can be used to increase customers' benefits ${ }^{39}$. Sirishia, Babo and Kishor believe that branding in health care system and hospitals relies on patients' experiences of the hospital and word of mouth marketing. They believe that customers are hospitals ambassadors. Thus, accelerating hospital buildings in India resulted in branding for hospitals and health care system by health care providers ${ }^{40}$.

Having the native situation of our country in mind and considering the actions of selective hospitals in developing hospital branding, using their experiences in Iran and regulating and resolution of policies and principle, it is suggested to look for branding strategy.

\section{REFERENCES}

1. Rafati,M; Zargar,S;Dehghan,R. "Case study of countries in the Eastern Mediterranean Region”, Hospital Journal, 2005; 5(9): 48-55(Persian).

2. Dragi,P.2015, The sayings and writings of the marketing teacher: Hospitals need branding, Retrived from www.dragi.ir/1228, Access Date:2015-8-11(Persian).

3. Mohammadian $\mathrm{M}$ and Bastani, A. “introducing marketing and its application for Hospitals and health care centers", Retrived from www.marketingarticles.ir, Access Date: 20154-21(Persian).

4. Doaei,H\&Hasanzadeh,Zh.2011, “Comparative Study of Customers atitude about global Clothes brands: case study of local brands, Iran, Korea and Japan”, Business Surveys,No.42(Persian).

5. Yasin,N.M.,Noor,N.N.\&Mohammad,O.2012, "Does image of country-of-origin matter to brand equity?”Journal of Product \& Brand Management, Vol. 16, No. 1,pp.38-48.

6. Vargo, S. L., \& Lusch, R. F. 2004, Evolving to a new dominant logic for marketing. Journal of marketing, Vol.68, No. 1,pp. 1-17.

7. Whelan, S. Davies, G. Walsh, M\& Bourke, R.2010, "Public sector corporate branding and customerOrientation”. Journal of business research,Vol. 63,pp. 1164-1171.

8. Calgary Development plan. 2015, Calgary Canada a great place to learn \& live, p. 1. 
9. Alberta Children's Hospital. 2014, Financial Statements of Alberta Children's Hospital Foundation, Year ended 2014, p. 2.

10. Alberta children's hospital. The Alberta Children's Foundation, Foundation is committed to service excellence, 2013; 1.

11. LG. 2014, LG Electronics Sustainability Report. Seoul, South Korea, p. 68.

12. RAK Free Trade Zone. 2014, Investment Opportunities In Ras Al Khaimah United Arab Emirates. Ras Al Khaimah United Arab Emirates, p. 5.

13. National Infocomm Awards. 2010, Closed Loop Medication Management System (CLMM), Seoul National University Hospital, p. 9.

14. SK Telecom. SK Telecom, targeting growth, 2013; 2: 9.

15. Research Programme of AIDS. Research Portfolio Center for AIDS Prevention Studies (CAPS), University of California San Francisco, 2006; 19.

16. Center for global Development. 2009, Partnerships with the Private Sector in Health What the International Community Can Do to Strengthen Health Systems in Developing Countries, Final Report of the Private Sector Advisory Facility Working Group, p. 30.

17. Health and Social Development report. Annual Report 2011-12 In terms of the Public Finance Management Act Rule, Gauteng Department of Health and Social Development, 2011; 1-418.

18. Health and Social Development report. 2010, Annual Report 2010-11 In terms of the Public Finance Management Act Rule, Gauteng Department of Health and Social Development, pp. 1-442.

19. Health Service Executive. 2009, Supplementary PR Data June 2009, pp. 1-125.

20. The Competition Authority. 2007, Competition in the Private Health Insurance Market January 2007, p.146.

21. European Social Charter. 2014, 12th National Report on the implementation of the European Social Charter, The Government of Ireland, p.36.

22. Ross, S. O’Callaghan, I. Kiely, R. Corcoran, D.Sleator, R., Lucey, B.2013, Isolation and characterisation of Verotoxigenic E.coli in acute gastroenteritis patients in the Cork Region. CERC-2013, p.295.

23. Ziqi, T. 2015, All-Round Marketing Increases Hospital Popularity, Cell Biochem Biophys, vol 72, pp. 367-370.

24. Zhang, P. 2015, Discussion on a Public Hospital's Practice in Culture Shaping and Innovative Development, Cell Biochem Biophys , vol 72, pp. 99-102.
25. Fiona Stanley Hospital. 2015, Patient information, Fiona Stanley Hospital, pp. 1-28.

26. Fiona Stanley Hospital. 2015, Fiona Stanley Hospital- our services from 2015, Find out what health care services we're delivering, [Online] Retrived from: http://www.fsh.health.wa.gov.au/ . [Accessed: 2nd August 2015].

27. Working Group for Achieving Quality. 2008, Recommendations to Improve Quality and the Measurement of Quality in New Zealand Emergency Departments, A Report from the Working Group for Achieving Quality in Emergency Departments to the Minister of Health, p. 29.

28. Middlemore Hospital. 2015, [Online] Middlemore Hospital public Hospital. Retrived from: http://www.healthpoint.co.nz/ middlemore-hospital/ . [Accessed: 1st August 2015].

29. Motamed Najar,K.2013,Interview for research at Hasheminejad Kidney Center(Persian).

30. Barzegar,M.2015, Interview for research at Hasheminejad Kidney Center(Persian).

31. Etemadian, M.2015, Interview for research at Hasheminejad Kidney Center(Persian).

32. Kiani, M.2015, Interview for research at Rajayi Cardiac Hospital (Persian).

33. Rajayi Cardiac Hospital Website:www. rhc.ac.ir(Persian).

34. Schmitt, B. 2012, “The consumer psychology of brands”. Journal of Consumer Psychology,Vol. 22, No.1, pp.7-17.

35. Sajadi,S.M.2010, Checking Saipa company's brand image by using Kapferer Model, Thesis for Master of Science,TUMS(Persian).

36. Nafisi,A.2010, The relationship between branding and performance indicators in the hospital Ghaem Mashhad, Thesis for Master of Science,Islamic Azad University, Science \& Research Branch(Persian).

37. Otoofi,A.2013, “ Brand equity in health care marketing: A Case Study of Tehran's hospitals”, Thesis for Master of Science,Alameh Tabatabaei University(Persian).

38. Sorayyaei,A\&Mehraei,S.2013, “Check ranking the appropriate marketing strategies in order to achieve competitive advantage in private hotels (3 to 5) Stars in Mazandaran”,Management Journal, Vol. 10, No. 30(Persian).

39. Kim K, Kim K, Kim D, Kim J, Kang S.2008, Brand equity in hospital marketing. Journal of business research, Vol. 61,pp. 75-82

40. Sirisha, B, Babu, M. K, 2014, "Branding of hospitals". International Journal of Multidisciplinary Management Studies, Vol .4, Iss.3,pp.227-237. 